\title{
Aktivitas Polifenol Teh Hijau (Camellia sinensis (L) O. Kuntze) Sebagai Imunomodulator melalui Respons Supresi Imunoglobulin E (IgE) pada Rinitis Alergika
}

\author{
Yusni, ${ }^{1}$ Teuku Husni T. R, ${ }^{2}$ Tri Hanggono Achmad ${ }^{3}$ \\ ${ }^{1}$ Bagian Fisiologi Fakultas Kedokteran Universitas Syiah Kuala, ${ }^{2}$ Departemen Ilmu Penyakit THT-KL Fakultas \\ Kedokteran Universitas Syiah Kuala ${ }^{3}$ Departemen Biokimia dan Biomolekuler Fakultas Kedokteran Universitas \\ Padjadjaran Bandung
}

\begin{abstract}
Abstrak
Rinitis alergika adalah kondisi inflamasi mukosa nasal yang diakibatkan oleh interaksi antara alergen dan imunoglobulin E (IgE). Imunomodulator merupakan bagian terpenting dalam pengobatan rinitis alergika dan salah satu tanaman obat yang mempunyai aktivitas imunomodulator adalah teh hijau (Camellia sinensis L.) terutama polifenol. Tujuan penelitian adalah menganalisis aktivitas polifenol teh hijau sebagai imunomodulator pada pasien rinitis alergika. Penelitian ini dilaksanakan dari bulan Juni-Desember 2011 di laboratorium Fisiologi Fakultas Kedokteran Unsyiah Banda Aceh dan pemeriksaan IgE dilakukan di laboratorium swasta. Desain penelitian adalah quasi experimental dengan rancangan pretest-posttest with control group. Subjek penelitian adalah 12 pasien rinitis alergika, yaitu 6 orang sebagai kelompok kontrol (diberikan plasebo) dan 6 orang sebagai kelompok perlakuan (diberikan kapsul polifenol teh hijau 2x350 mg/hari, selama 14 hari). Analisis data menggunakan uji normalitas, uji homogenitas, dan uji-t $(\mathrm{p}<0,05)$. Hasil penelitian menunjukkan kadar imunoglobulin E sesudah pemberian perlakuan pada kelompok perlakuan lebih rendah dibanding dengan kelompok kontrol $(1.475,2 \pm 940,7$ vs $494,3 \pm 366,5 \mathrm{IU})$, namun tidak bermakna $(\mathrm{p}=0,05)$. Simpulan pemberian polifenol teh hijau menurunkan sekresi IgE, namun tidak bermakna dan membutuhkan penelitian lebih lanjut. [MKB. 2015;47(3):160-66]
\end{abstract}

\section{Activity of Green Tea (Camellia sinensis (L) 0. Kuntze) Polyphenols as Immunomodulator through Response of Suppression Immunoglobulin E (IgE) in Allergic Rhinitis}

\begin{abstract}
Allergic rhinitis is an inflammatory condition of the nasal mucosa caused by interactions between allergens and immunoglobulin E (IgE). Immunomodulatory is an important part of the treatment of allergic rhinitis. One of the medicinal plants that have immunomodulatory activities is green tea (Camellia sinensis L.), specifically polyphenols. The purpose of this study was to analyze the activity of green tea's polyphenols as an immunomodulator in patients with allergic rhinitis. This study was conducted in June to December 2011 in the laboratory of Physiology, Faculty of Medicine Unsyiah with the IgE examinations conducted in private laboratories. This study is a pretest-postest quasi experimental study with control group design. Subjects were 12 patients with allergic rhinitis; 6 people were included in the control group (placebo) and 6 in the treatment group (green tea's polyphenols 2x350 mg/day, for 14 days). Analysis of the data was performed using the normality test, homogeneity test, and t-test $(p<0.05)$. The results showed that the levels of immunoglobulin $\mathrm{E}$ after the administration of green tea's polyphenols in the treatment group was lower than the control group (1.475.2 \pm 940.7 vs $494.3 \pm 366.5$ IU), but not significantly $(\mathrm{p}=0.05)$. In conclusion, the administration of green tea's polyphenols can insignificantly decrease the secretion of IgE. Hence, further research is required. [MKB. 2015;47(3):160-66]
\end{abstract}

Key words: Allergic rhinitis, immunoglobulin E, immunomodulator, green tea's polyphenols (Camellia sinensis L.)

Korespondensi: Yusni, dr., Bagian Fisiologi Fakultas Kedokteran Universitas Syiah Kuala Darussalam Banda Aceh, mobile 0811225692, e-mail yusni_johan@yahoo.com 


\section{Pendahuluan}

Gangguan sistem imunitas tubuh akan memiliki berdampak terhadap timbulnya penyakit dan salah satu penyakit akibat gangguan sistem imun khususnya imun yang spesifik adalah rinitis alergika. ${ }^{1,2}$ Rinitis alergika adalah kelainan pada hidung dengan gejala seperti bersin-bersin, hidung berair, hidung gatal, dan juga tersumbat setelah mukosa hidung terpapar alergen yang diperantarai oleh imunoglobulin E (IgE). ${ }^{3}$ Rinitis alergi merupakan masalah kesehatan global yang memengaruhi $10-20 \%$ seluruh populasi. Prevalensi rinitis alergika di Eropa sekitar 7-18\%, sedangkan di Amerika 10-30\% pada pasien dewasa dan mencapai $40 \%$ pada pasien anak-anak. Prevalensi rinitis alergika di Korea dari November 1999 sampai April 2000 adalah $3,39 \% .{ }^{4}$ Hasil survei di Korea yang dilakukan oleh International Study of Asthma and Allergies in Childhood (ISSAC) terhadap 42.886 anak usia 6-12 tahun dan 12-15 tahun menyatakan prevalensi rinitis alergika adalah $28,8 \%$ dan 29,1\%. ${ }^{5}$ Angka prevalensi rinitis alergika di beberapa rumah sakit besar di Indonesia sekitar $10-26 \%{ }^{6}$

Perkembangan dunia kedokteran saat ini mulai mengarah kepada pengobatan herbal atau yang dikenal dengan istilah herbal medicine, yaitu pengobatan dengan menggunakan obatobatan herbal (bahan alam, seperti tanaman obat di antaranya teh hijau). Saat ini, masyarakat Asia termasuk Indonesia mempercayai bahwa teh hijau mengandung zat yang berguna untuk pencegahan dan penyembuhan berbagai jenis penyakit antara lain sebagai antikarsinogenik, antimetastatik, antioksidatif, antihipertensi, antihiperkolesterolemia, antikaries gigi, antibakterial, dan imunomodulator atau antialergi. Hasil penelitian oleh Maeda-Yamamoto dkk. ${ }^{7}$ menemukan bahwa teh hijau bermanfaat sebagai antialergi. Hal ini diduga karena daun teh hijau mengandung senyawa aktif yang dipercaya untuk bertanggung jawab dalam memberikan kontribusi positif bagi kesehatan manusia, yaitu polifenol.

Polifenol ialah antioksidan yang kekuatannya 100 kali lebih efektif dibanding dengan vitamin C dan 25 kali lebih tinggi dibanding dengan vitamin E. Selain itu, diduga polifenol teh hijau juga mempunyai aktivitas sebagai antiinflamasi dan antialergi. Salah satu komponen polifenol adalah epigallocatechingallate (EGCG) yang berperan dalam menstimulasi produksi interleukin-1 alpha (IL-1 $\alpha$ ), interleukin-1 beta (IL-1 $\beta$ ), tumor necrosis factor alpha (TNF- $\alpha)^{7,8}$
EGCG juga dapat membantu proses fagositosis, meningkatkan ketahanan limfosit, proliferasi limfosit, sekresi IL-12 makrofag, meningkatkan IFN- $\gamma$, dan menghambat pengeluaran histamin. EGCG juga berperan menghambat ikatan antara FceRI dan IgE sehingga akan menghambat pengeluaran histamin. FceRI berperan penting dalam penginduksi dan juga mempertahankan respons alergi yang diperantarai oleh IgE seperti pada rinitis alergika. ${ }^{9}$ FceRI juga berfungsi sebagai reseptor IgE yang menempel pada permukaan sel mast atau basofil dan berperan dalam menghambat IL-2 yang bersumber dari sel T. Hambatan IL-2 akan memberi efek terhadap fungsi IL-2 yang secara normal merespons sel $B$ untuk mengeluarkan antibodi dan salah satu antibodi yang dihambat pengeluarannya adalah IgE sehingga akhirnya akan mengurangi kadar IgE pada pasien rinitis alergika. ${ }^{6,7}$ Penelitian ini bertujuan menganalisis aktivitas polifenol teh hijau yaitu sebagai imunomodulator dengan menurunkan sekresi IgE pada pasien rinitis alergika.

\section{Metode}

Penelitian ini merupakan penelitian quasi experimental dengan rancangan pretest-posttest with control group. Penelitian dilaksanakan dari bulan Juni sampai Desember 2011 di Laboratorium Fisiologi Fakultas Kedokteran Unsyiah Aceh. Pemeriksaan kadar imunoglobulin E dilakukan di Laboratorium Prodia Jakarta, pembuatan ekstrak teh hijau dilakukan di Laboratorium Kimia Fakultas Matematika dan Ilmu Pengetahuan Alam (MIPA) Universitas Syiah Kuala (Unsyiah), dan sampel darah penderita rinitis alergika diperoleh dari Panti Asuhan Nirmala yang terletak di daerah Lampineung Banda Aceh. Daun teh diambil dari perkebunan teh Halaban di Kabupaten Lima Puluh Kota, Padang, Sumatera Barat. Daun teh yang diambil adalah daun teh yang muda atau pucuknya dan umurnya tidak diketahui secara pasti.

Subjek penelitian adalah penderita rinitis alergika, usia 13 sampai 19 tahun, laki-laki dan perempuan yang berjumlah 12 orang, terdiri atas 3 laki-laki dan 9 perempuan. Subjek dibagi menjadi 2 kelompok, yaitu 6 orang kelompok kontrol dan 6 orang kelompok perlakuan. Kriteria inklusi adalah penghuni Panti Asuhan Nirmala dengan diagnosis rinitis alergika dan usia 13-19 tahun. Kriteria eksklusi adalah tidak mengonsumsi kapsul polifenol teh hijau secara teratur, mengonsumsi obat antialergi lain secara 
rutin selain sediaan kapsul polifenol teh hijau, penderita yang tidak kooperatif, memiliki kadar IgE normal, dan menderita penyakit infeksi.

Metode pengambilan subjek pada penelitian ini berdasarkan jumlah populasi yang memenuhi kriteria inklusi dan tidak termasuk kriteria eksklusi. Cara pengambilan subjek ialah sebagai berikut: jumlah penghuni panti sebanyak 135 anak dan dari 135 anak didapatkan 40 anak yang memiliki riwayat bersin berulang (data diambil berdasarkan rekam medis klinik kesehatan Panti Asuhan Nirmala). Selanjutnya, ke-40 anak tersebut dilakukan anamnesis, pemeriksaan fisis, dan juga pemeriksaan konka oleh dokter spesialis Telinga Hidung Tenggorok Kepala dan Leher (THT-KL) dan didapatkan sebanyak 20 anak memiliki suspek rinitis alergika. Sebanyak 20 anak tersebut diminta kesediaannya untuk menjadi subjek penelitian, namun hanya 13 anak yang bersedia dan selanjutnya dilakukan pemeriksaan kadar IgE. Hasil pemeriksaan kadar IgE didapatkan 1 anak dengan kadar IgE normal dan 12 anak memiliki kadar IgE tinggi digunakan sebagai subjek penelitian. Jumlah subjek sesuai dengan metode convenience sampling, yaitu metode pengambilan sampel yang didasarkan atas jumlah anggota populasi yang bersedia menjadi sampel dan memenuhi syarat penelitian.

Penentuan kelompok untuk subjek masingmasing dilakukan dengan cara acak sederhana dengan menggunakan undian, yaitu sebanyak 12 nama ditulis dalam secarik kertas dan digulung, kemudian dikocok, 6 nama yang jatuh pertama dipergunakan sebagai kelompok perlakuan, sedangkan 6 nama terakhir dijadikan sebagai kelompok kontrol. Kelompok perlakuan diberikan kapsul polifenol teh hijau 2x350 mg/ hari, diberikan pagi hari (jam 07.00-07.30 WIB) dan sore hari (jam 18.00-18.30 WIB) setelah makan, sedangkan kelompok kontrol diberikan kapsul plasebo yang berisi gula tepung dengan jadwal pemberian sama dengan kelompok perlakuan.

Pengambilan darah dilakukan dengan cara intravena di mediana kubiti, darah diambil sebanyak $3 \mathrm{~mL}$ dan dimasukkan ke dalam tabung reaksi, lalu ditambahkan antikoagulan ethylen ediamine tetraacetic acid (EDTA). Selanjutnya, darah dibawa ke laboratorium Prodia Banda Aceh, dilakukan pemisahan serum dan besoknya

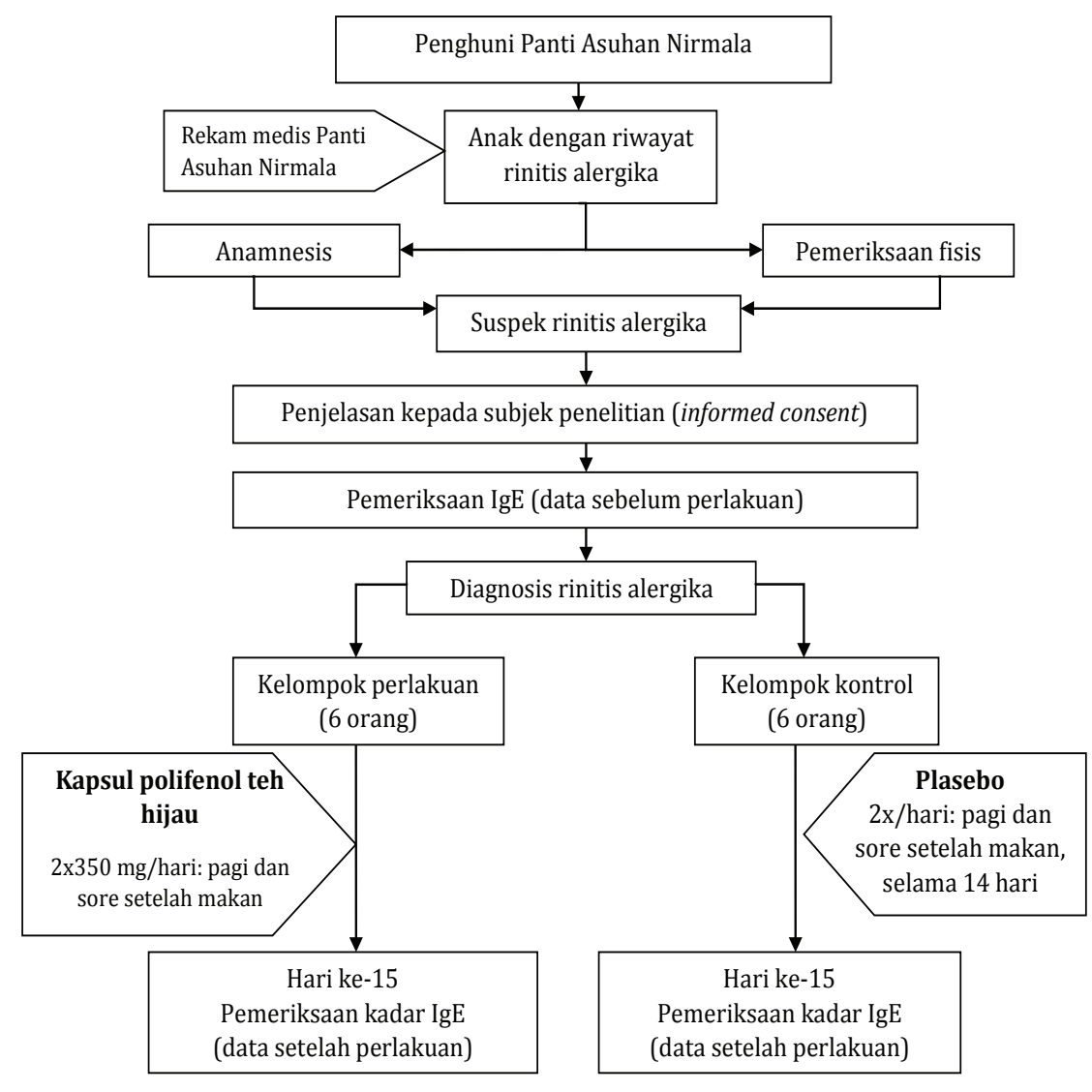

Gambar Prosedur Penelitian 
Yusni: Aktivitas Polifenol Teh Hijau (Camellia sinensis (L) O. Kuntze) Sebagai Imunomodulator melalui Respons Supresi IgE

Tabel 1 Data Karakteristik Fisik Fisiologis Subjek Penelitian

\begin{tabular}{|c|c|c|c|c|c|}
\hline Variabel & Kelompok & $\mathbf{n}$ & Rata-rata & SD & Nilai p \\
\hline \multirow[t]{2}{*}{ Usia } & Kontrol & 6 & 15,50 & 1,04 & \multirow{2}{*}{0,15} \\
\hline & Perlakuan & 6 & 14,66 & 0,81 & \\
\hline \multirow[t]{2}{*}{ Berat badan } & Kontrol & 6 & 45,58 & 1,68 & \multirow{2}{*}{0,17} \\
\hline & Perlakuan & 6 & 42,80 & 0,86 & \\
\hline \multirow{2}{*}{ Tinggi badan } & Kontrol & 6 & 155,66 & 2,55 & \multirow{2}{*}{0,29} \\
\hline & Perlakuan & 6 & 152,33 & 1,56 & \\
\hline \multirow{2}{*}{ IMT } & Kontrol & 6 & 18,85 & 1,34 & \multirow{2}{*}{0,63} \\
\hline & Perlakuan & 6 & 18,48 & 1,24 & \\
\hline \multirow{2}{*}{ Sistol } & Kontrol & 6 & 111,66 & 11,69 & \multirow{2}{*}{0,36} \\
\hline & Perlakuan & 6 & 106,66 & 5,16 & \\
\hline \multirow{2}{*}{ Diastol } & Kontrol & 6 & 75,00 & 8,36 & \multirow{2}{*}{0,48} \\
\hline & Perlakuan & 6 & 78,33 & 7,32 & \\
\hline
\end{tabular}

Keterangan: $p>0,05$, data menunjukkan tidak berbeda nyata, IMT = Indeks massa tubuh

darah dikirim ke laboratorium Prodia Jakarta mempergunakan dry ice. Pengambilan darah dan juga pengirimannya dilakukan oleh staf Laboratorium Klinik Prodia Banda Aceh.

Alat-alat yang digunakan pada penelitian ini, yaitu senter kepala, spekulum hidung, disposible spuit $10 \mathrm{cc}$, torniquet, tabung eppendorf, tabung reaksi, sentrifuge, tabung sentrifuge, micropipet, bilik hitung, luminair flow, mikroskop, inkubator, spektrofotometer, dan juga cuvet. Alat untuk pembuatan ekstrak: rotari evaporator, toples, timbangan, gelas ukur, dan corong.

Bahan penelitian adalah sampel darah, alkohol 70\%, serta EDTA, polifenol teh hijau, etanol 96\%, kapsul 00, serum darah, lite reagent ( $5 \mathrm{~mL} / \mathrm{pak}$ ), solid phase (22,5 mL/pak), acid reagent (reagen asam), base reagent (reagen basa), dan reagent air. Reagent ADVIA Centaur Total IgE Assay untuk pemeriksaan kadar IgE.

Penelitian ini dilakukan setelah persetujuan dari Komisi Etik Penelitian Kedokteran Fakultas
Kedokteran Universitas Syiah Kuala Banda Aceh nomor 090/KE/FK/2011. Analisis data hasil penelitian menggunakan uji homogenitas varians menurut Levane, uji-t normalitas data dengan Kolmogorof-Smirnov dan uji t untuk data berpasangan. Prosedur penelitian dapat dilihat pada Gambar.

\section{Hasil}

Gambaran karakteristik fisik fisiologis subjek penelitian yaitu berupa usia, berat badan, tinggi badan, IMT, dan tekanan darah antara kelompok kontrol dan kelompok perlakuan tidak berbeda ( $p>0,05)$, seperti yang terlihat pada Tabel 1 .

Berdasarkan hasil uji homogenitas varians mempergunakan Uji Levene $(p>0,05)$ terhadap kadar IgE serum sebelum perlakuan didapatkan hasil varians data homogen dan juga hasil uji normalitas mempergunakan Uji Kolmogorof-

Tabel 2 Uji-t untuk Mengetahui Perbedaan Kadar IgE Sebelum dan Sesudah Perlakuan pada Kedua Kelompok

\begin{tabular}{lllcccc}
\hline IgE $(\mathbf{I U})$ & \multicolumn{1}{c}{ Kelompok } & $\mathbf{n}$ & Rata-rata & SD & t & $\mathbf{p}$ \\
\hline $\begin{array}{l}\text { Sebelum } \\
\text { perlakuan }\end{array}$ & Kontrol & 6 & $1.505,7$ & 931,6 & $-2,3$ & 0,04 \\
& Perlakuan & 6 & 515,7 & 432,3 & & \\
$\begin{array}{l}\text { Setelah } \\
\text { perlakuan }\end{array}$ & Kontrol & 6 & $1.475,2$ & 940,7 & $-2,3$ & 0,03 \\
& Perlakuan & 6 & 494,3 & 368,5 & & \\
\hline
\end{tabular}

Keterangan: * bermakna pada taraf kekeliruan $5 \%(p<0,05)$ 
Tabel 3 Uji-t Untuk Mengetahui Pengaruh Pemberian Perlakuan terhadap Kadar IgE pada Kelompok Kontrol dan Perlakuan

\begin{tabular}{lllcccc}
\hline $\begin{array}{c}\text { Kelompok } \\
\text { Ig E (IU) }\end{array}$ & \multicolumn{1}{c}{ Perlakuan } & n & Rata-rata & SD & t & p \\
\hline \multirow{2}{*}{ Kontrol } & Sebelum & 6 & $1.505,7$ & 940,7 & 0,15 & 0,88 \\
& Setelah & 6 & $1.475,3$ & 931,6 & & \\
\multirow{2}{*}{ Perlakuan } & Sebelum & 6 & 515,7 & 432,3 & & \multirow{2}{*}{0,53} \\
& Setelah & 6 & 494,3 & 368,5 & & \\
\hline
\end{tabular}

Keterangan: * bermakna pada taraf kekeliruan 5\% $(\mathrm{p}<0,05)$

Smirnof $Z$ memperlihatkan kadar IgE serum sebelum perlakuan yang berdistribusi normal sehingga uji lanjutan yang dilakukan adalah uji-t untuk data tidak berpasangan dan berpasangan.

Hasil uji-t $(\mathrm{p}<0,05)$ data tidak berpasangan untuk mengetahui perbedaan kadar IgE sebelum perlakuan dengan setelah perlakuan pada kelompok kontrol dan perlakuan tertera pada Tabel 2. Berdasarkan hasil uji-t data berpasangan $(p<0,05)$ seperti pada Tabel 2 menunjukkan kadar IgE sebelum pemberian perlakuan antara kelompok kontrol dan kelompok perlakuan terdapat perbedaan $(p=0,04)$, demikian juga kadar IgE setelah diberikan perlakuan antara kelompok kontrol dan perlakuan didapatkan perbedaan yang bermakna $(p=0,03)$. Untuk mengetahui ada tidaknya pengaruh pemberian kapsul polifenol teh hijau terhadap kadar IgE pada kelompok masing-masing, dilakukan suatu perbandingan kadar IgE setelah pemberian perlakuan pada kedua kelompok. Hasil uji-t tersebut dapat dilihat pada Tabel 3.

Seperti yang terlihat pada Tabel 3, hasil uji-t data berpasangan $(p<0,05)$ untuk mengetahui pengaruh pemberian kapsul polifenol teh hijau terhadap kadar IgE pada kelompok perlakuan didapatkan hasil bahwa kadar IgE sebelum dan setelah diberikan kapsul polifenol teh hijau selama 14 hari ternyata tidak memperlihatkan penurunan yang bermakna $(p=0,53)$. Hal ini mengindikasikan bahwa kapsul polifenol teh hijau tidak dapat menurunkan kadar IgE serum pada pasien rinitis alergika.

\section{Pembahasan}

Hasil penelitian menunjukkan penurunan kadar IgE serum pada pasien rinitis alergika setelah diberikan kapsul polifenol teh hijau selama 14 hari, namun hasil analisis statistik menunjukkan penurunan kadar IgE tersebut tidak berbeda bermakna. Hasil penelitian ini tidak sesuai dengan teori yang menyatakan bahwa daun teh mengandung senyawa aktif, yaitu polifenol., ${ }^{8,10}$ Ada empat komponen utama yang terdapat pada polifenol teh hijau, yaitu epicatechin (EC), epigallocatechin (EGC), epicatechin-3-Ogallate (ECG), dan epigallocatechin-3-O-gallate (EGCG). ${ }^{11}$ Salah satu yang berfungsi sebagai antialergi adalah epigallocatechin-3-O-gallate (EGCG). EGCG adalah catechins yang paling umum dan paling aktif pada teh hijau dengan konsentrasi fisiologis 0,1-10 mikromolar., ${ }^{8,10-12}$ EGCG juga merupakan komponen utama teh hijau yang berperan pula dalam menghambat IL-2 yang bersumber dari sel T. Hambatan ini akan memberi efek pada fungsi IL-2 yang secara normal merespons sel B untuk mengeluarkan antibodi. Salah satu antibodi yang dihambat pengeluarannya adalah IgE sehingga akan mengurangi kadar IgE pada rinitis alergika. ${ }^{8}$

Rinitis alergika terjadi karena alergen asing yang masuk sehingga merespons sel $\mathrm{T}$ untuk berdiferensiasi menjadi $\mathrm{Th}_{2}$. $\mathrm{Th}_{2}$ merangsang pengeluaran sitokin seperti IL-4, IL-3, IL-5, dan IL-13. Pengeluaran IL-4 mengaktivasi sel B, kemudian sel B menginduksi major histocompatibility complex atau MHC II dan FcepsilonRI (FceRI) serta juga dapat merangsang pengeluaran IgE oleh sel mast. ${ }^{3,9} \mathrm{FccR}$ RI berperan pentingdalam penginduksi dan mempertahankan respons alergi yang diperantarai oleh IgE dan juga sebagai reseptor IgE yang menempel pada permukaan sel mast atau basofil seperti pada rinitis alergika. EGCG berperan pula dalam menghambat IL-2 yang bersumber dari sel T. Hambatan ini akan memberi efek pada fungsi IL-2 yang secara normal merespons sel B untuk mengeluarkan antibodi. Salah satu antibodi yang dihambat pengeluarannya adalah IgE sehingga akan mengurangi kadar IgE.7,8 
Hasil penelitian ini sesuai dengan hasil penelitian di Jepang yang dilakukan oleh Maeda-Yamamoto dkk. ${ }^{7}$ menggunakan subjek penelitian penderita rinitis alergika laki-laki dan perempuan, usia di atas 22 tahun. Subjek mengonsumsi ekstrak teh hijau, yaitu sebanyak 1,5 g teh hijau yang mengandung 8,5 mg EGCG Me' dan 43,5 mg EGCG yang diberikan selama 11 minggu. Hasilnya tidak terdapat efek teh hijau terhadap respons imun normal yang salah satunya adalah imunoglobulin E, namun mereka menyatakan bahwa EGCG teh hijau berpotensi sebagai antialergi karena hasil penelitian tersebut menunjukkan penurunan gejala rinitis alergika. EGCG tersebut berperan menghambat ikatan antara FceRI (reseptor imunoglobulin E) dan IgE sehingga akan menghambat pengeluaran histamin. Hal ini tentunya akan berdampak pada penurunan gejala rinitis alergika. ${ }^{7,8,10}$

Namun, hasil penelitian ini berbeda dengan penelitian lainnya yang dilakukan oleh Hassanain dkk. ${ }^{13}$ di New York tentang peran teh hijau secara in vitro dengan melakukan kultur terhadap sel yang menyekresi IgE selama 72 hari. Penelitian dilakukan pada 2 kelompok, yaitu kelompok yang diberi ekstrak teh hijau dan kelompok tanpa ekstrak teh hijau. Hasilnya menunjukkan ekstrak teh hijau berperan terhadap penurunan kadar imuniglobulin E dengan menekan sel B dalam memproduksi imunoglobulin E tanpa diikuti dengan kematian sel $\mathrm{B}$ atau apoptosis.

Hasil penelitian ini tidak sesuai dengan teori dan hasil penelitian lainnya kemungkinan karena proses ekstraksi polifenol, yaitu suhu pemanasan ekstrak. ${ }^{13}$ Suhu pemanasan ekstrak itu ternyata sangat memengaruhi kandungan catechin yang ada dalam teh hijau..$^{12,13}$ Kandungan catechin yang paling tinggi yaitu pada suhu $118,1^{\circ} \mathrm{C}$ dibanding dengan suhu $50^{\circ} \mathrm{C}, 70^{\circ} \mathrm{C}$, dan $90^{\circ} \mathrm{C}$. Ekstrak dalam penelitian ini dipanaskan pada suhu $45^{\circ} \mathrm{C}$ sehingga kemungkinan hasil kandungan catechin yang diperoleh hanya sedikit. Hal itu tentunya sangat memengaruhi hasil penelitian karena komponen utama dalam teh hijau yang sangat bermanfaat sebagai antialergi adalah catechin. Hal lain yang mungkin menjadi faktor yang dapat memengaruhi hasil penelitian adalah zat aktif yang diekstrak adalah polifenol, sedangkan komponen utama polifenol yang berperan sebagai imunomodulator adalah EGCG. ${ }^{8,10}$ EGCG lebih baik dalam menghambat alergi tipe I dibanding dengan EGCG. Selain itu, menurut informasi dari laboratorium FMIPA Unsyiah, yang diekstrak memang benar polifenolnya, namun apakah prosedurnya sesuai, kami tidak diberitahukan informasi secara akurat. Kemungkinan lainnya adalah jumlah subjek yang digunakan pada penelitian ini hanya 12 orang dan perlakuannya hanya 14 hari. Hal ini juga yang mendorong kami akan melakukan penelitian lanjutan dengan menggunakan subjek penelitian yang lebih banyak, waktu perlakuan lebih lama, dan melakukan ekstraksi polifenol dari teh hijau dengan suhu yang sesuai pada laboratorium lain di luar Unsyiah.

Hasil penelitian ini dapat disimpulkan bahwa polifenol teh hijau dapat menurunkan sekresi imunoglobulin E pada pasien rinitis alergika. Hal ini menunjukkan bahwa teh hijau tidak dapat mensupresi sekresi IgE dan tidak mempunyai aktivitas sebagai imunomodulator sehingga teh hijau belum dapat dipergunakan sebagai terapi imunomodulator pada rinitis alergika dan masih membutuhkan penelitian lebih lanjut.

\section{Daftar Pustaka}

1. Amarasekera $M$. Immunoglobulin $E$ in health and disease. Asia Pac Allergy. 2011;1:12-5.

2. Baratawidjaja KG, Rengganis I. Imunologi dasar. Edisi ke-10. Fakultas Kedokteran Universitas Indonesia: Jakarta; 2010.

3. Irawati N, Kasakeyan E, Rusmono N. Rinitis alergi. Dalam: Soepardi EA, Iskandar N, Bashiruddin J, Restuti RD, penyunting. Buku ajar ilmu kesehatan telinga hidung tenggorok kepala dan leher. Edisi ke-6. Jakarta: Fakultas Kedokteran Universitas Indonesi; 2007. hlm. 128-34.

4. Canonica GW, Compalati E. Minimal persistent inflammation in allergic rhinitis: implication for current treatment strategies. J Translational Immunol. 2009;158(3):26071.

5. Min YG. The pathophysiology, diagnosis and treatment of allergy rhinitis. Allergy Asthma Immunol Res. 2010;2(2):65-76.

6. Rahmawati, Punagi AQ, Savitri E. Relation between rhinitis severity, skin prick test reactivity and mite-specifec immunoglobulin $\mathrm{E}$ in allergic rinitis patients in Makasar. Indonesian J Med Sci. 2008;1(1):1-7.

7. Maeda-Yamamoto M, Ema K, Shibuichi I. In vitro and in vivo anti-allergic effects of 'benifuuki' green tea containing 0 -methylated catechin and ginger extract enhancement. Cytotechnology. 2007;55:135-42.

8. Tachibana H. Green tea polyphenol sensing. Japan Academy. 2011;87(3):66-80.

9. Abbas AK, Lichtman AH, Pallai S. Cellular and molecular immunology. Edisi ke-6. 
Philadelphia: Saunders Elsevier; 2010.

10. Chacko SM, Thambi PT, Kuttan R, Nishigaki I. Beneficial effects of green tea: a literature review. Chinese Med. 2010;5(13):1-9.

11. Kapetanovic IM, Crowell JA, Krishnaraj $\mathrm{R}$, Zakharov $\mathrm{A}$, Lindebland $\mathrm{M}$, Lyubimov A. Exposure and toxicity of green tea polyphenols in fasted and non-fasted dogs. National Institutes of Health. 2009;260(13): 28-36.
12. Nance CL, Siwak AB, Shearer WT. Preclinical development of the green tea catechin, epigallocatechin gallate, as an HIV-1 therapy. J Allergy Clin Immunol. 2009;123(2):45965.

13. Hassanain E, Silverberg JI, Norowitz KB, Chice S, Bluth MH, Brody N, dkk. Green tea (Camellia sinensis) supresses B cell production of IgE without inducing apoptosis. Annals Clin Lab Sci. 2010;40(2):135-43. 